\title{
24. CHEMICAL VARIATION IN GLASS-WHOLE ROCK PAIRS FROM INDIVIDUAL COOLING UNITS IN HOLES 417D AND 418A ${ }^{1}$
}

\author{
H. Staudigel, ${ }^{2}$ Massachusetts Institute of Technology, Cambridge, Massachusetts \\ and
}

W.B. Bryan and G. Thompson, Woods Hole Oceanographic Institution, Woods Hole, Massachusetts

\section{INTRODUCTION}

The excellent core recovery at Sites 417 and 418 has made it possible to define many discrete cooling units, of which many are preserved as a complete interconnected core. A "cooling unit" is any physically distinct rock unit bounded by identifiable chilled margins, and may be of extrusive or intrusive igneous origin. The dimensions of a unit may vary accordingly, from half a meter or less in the case of a pillow cross-section, to tens of meters in the case of a massive flow or sill. A cooling unit may or may not coincide with a lithologic unit or chemical unit. A pillowed lava flow may be made up of hundreds of cooling units which are indistinguishable on chemical and petrographic criteria, whereas a massive flow may be chemically and petrographically distinct from cooling units above and below; in the latter case the massive flow might represent a single cooling unit which also is a distinct chemical and lithologic unit.

Many of the cooling units recognized in Holes 417D and $418 \mathrm{~A}$ show significant textural and mineralogical variation. There is always a general coarsening of grain size from the glassy rim toward a central zone which may have a doleritic, holocrystalline texture. Phenocrysts also vary considerably in abundance and in the relative proportions of plagioclase, olivine, and pyroxene comprising the phenocryst assemblage, though in these cores plagioclase is always the dominant phenocryst phase.

For this preliminary study we have selected crystalline rock samples which are closely associated with glass selected for microprobe analysis at the Smithsonian Institution and included in the glass data set reported by Byerly and Sinton (this volume). In this preliminary investigation we have not attempted to define the total extent of chemical variation throughout a complete cooling unit, but have limited the investigation to a comparison of these closely associated glass-whole rock pairs.

\section{ANALYTICAL TECHNIQUES}

Rock chips were carefully hand picked to remove palagonite, carbonate, altered zones, and smectite veins to minimize alteration effects in the geochemical data. Major elements were determined by X-ray fluorescence analyses (XRF) on fused glass discs following the technique of Norrish and Hutton (1969). Precision and accuracy of the

\footnotetext{
${ }^{1}$ Woods Hole Oceanographic Institution Contribution 4176.

${ }^{2}$ Present address: Ruhr-Universität Bochum, Institut für Mineralogie, Postfach 2148, West Germany.
}

technique is indicated in Table $1 \mathrm{~A}$ from the analyses of the USGS reference rock W-1.

The trace elements $\mathrm{Ni}, \mathrm{Co}, \mathrm{Cr}, \mathrm{Cu}, \mathrm{Zn}, \mathrm{V}, \mathrm{Y}, \mathrm{Zr}, \mathrm{Sr}$, and $\mathrm{Rb}$ were determined by XRF on powdered samples following the technique of Brown et al. (1973). The accuracy of the technique is indicated from analyses of reference rocks in Table 1B. Precision is generally better than \pm 5 per cent. In some cases (indicated in Tables 2 and 3) $\mathrm{Co}, \mathrm{Cr}, \mathrm{Hf}$, and $\mathrm{Sc}$ were determined by instrumental neutron activation analysis (INAA), and $\mathrm{Sr}$ and $\mathrm{Rb}$ by isotope dilution mass spectrometry (IDMS). Indication of the precision and accuracy of these measurements can be found in Frey et al. (1974) and Hart and Brooks (1974). Other indications of the precision and accuracy can be found from analyses of interlaboratory standards (Staudigel, this volume). $\mathrm{B}, \mathrm{Li}$, and $\mathrm{Ba}$ were determined by direct-reading optical emission spectrometry. Details of the technique and precision and accuracy $( \pm 10 \%)$ can be found in Thompson and Bankston (1969).

Concurrent with this study, a selection of these same samples was analyzed for rare earth elements and for strontium and oxygen isotopes. These data are presented and discussed in detail in separate presentations (Staudigel, Hart, and Frey, this volume; Muehlenbachs, this volume).

Minerals were analyzed by the computer-automated electron microprobe at the Massachusetts Institute of Technology. Standards and correction procedures are the same as in our previous studies of DSDP material (Frey et al., 1974). Interlaboratory comparisons performed by Jarosewich et al. (1978) and Staudigel (this volume) show that the agreement for all major elements is generally good; $\mathrm{Na}$ shows considerable scatter. No systematic difference

TABLE 1A

X-Ray Fluorescence Major Element Analyses of Reference Rock W-1 Run With Site 417 and 418 Samples

\begin{tabular}{lccc}
\hline & Mean Composition & \\
& & Standard Deviation & Recommended $^{\mathrm{b}}$ \\
\hline $\mathrm{SiO}_{2}$ & 53.36 & \pm 0.318 & 52.97 \\
$\mathrm{TiO}_{2}$ & 1.09 & \pm 0.007 & 1.08 \\
$\mathrm{Al}_{2} \mathrm{O}_{3}$ & 15.20 & \pm 0.099 & 15.12 \\
$\mathrm{FeO}$ & 10.23 & \pm 0.043 & 10.04 \\
$\mathrm{MgO}$ & 6.78 & \pm 0.182 & 6.66 \\
$\mathrm{CaO}$ & 10.94 & \pm 0.779 & 11.03 \\
$\mathrm{Na}_{2} \mathrm{O}$ & 2.42 & \pm 0.267 & 2.16 \\
$\mathrm{~K}_{2} \mathrm{O}$ & 0.65 & \pm 0.001 & 0.64 \\
$\mathrm{P}_{2} \mathrm{O}_{5}$ & 0.15 & \pm 0.003 & 0.14 \\
$\mathrm{MnO}$ & 0.17 & \pm 0.001 & 0.17 \\
\hline
\end{tabular}

Mean and standard deviation of 10 analyses.

${ }^{b}$ From Flanagan, 1973, corrected for ignition loss.

${ }^{\mathrm{c}}$ Total Fe reported as FeO. 
TABLE 1B

X-Ray Fluorescence Trace Element Analyses of Reference Rocks Run with Site 417 and 418 Samples

\begin{tabular}{|c|c|c|c|c|c|c|}
\hline & \multicolumn{2}{|c|}{ BCR-1 } & \multicolumn{2}{|r|}{ W-1 } & \multicolumn{2}{|c|}{ MRG-1 } \\
\hline & Found & Recomm. $^{\mathrm{a}}$ & Found & Recomm. $^{a}$ & Found & Recomm. $^{\mathrm{b}}$ \\
\hline $\mathrm{Zn}$ & 123 & 120 & 83 & 86 & 184 & 185 \\
\hline $\mathrm{Cu}$ & 21 & 18 & 112 & 110 & 129 & 135 \\
\hline $\mathrm{Ni}$ & 16 & 16 & 78 & 76 & 190 & 200 \\
\hline $\mathrm{Cr}$ & 15 & 17 & 117 & 114 & 419 & 420 \\
\hline $\mathrm{V}$ & 398 & 399 & 262 & 264 & 541 & 520 \\
\hline Co & 35 & 37 & 47 & 47 & 86 & 87 \\
\hline $\mathrm{Z}_{\mathrm{r}}$ & 187 & 190 & 103 & 105 & 107 & 100 \\
\hline $\mathrm{Y}$ & 37 & 37 & 25 & 25 & 17 & 20 \\
\hline $\mathrm{Sr}$ & 329 & 330 & 191 & 190 & 269 & 260 \\
\hline $\mathrm{Rb}$ & 47 & 47 & 22 & 21 & 7 & 8 \\
\hline
\end{tabular}

${ }^{2}$ Flanagan, 1973.

bAbbey, 1976.

between the Smithsonian and M.I.T. probes could be detected.

\section{PETROGRAPHY AND MINERALOGY}

The major phenocryst phases are plagioclase, olivine, and clinopyroxene. Magnetite occurs both as microphenocrysts and groundmass microlites. Spinel was found as a minor phenocryst phase in Hole 418A basalts. Where plagioclase occurs in varying proportions $(5-25$ vol. \%) throughout both Holes 417D and 418A, olivine and clino- pyroxene roughly increase in abundance towards the base of Hole 418A. Their abundance varies from 0 to 5 vol. per cent (olivine) and from 0 to $7 \mathrm{vol}$. per cent (clinopyroxene). Major changes in liquid (glass) composition, as given by Byerly and Sinton (this volume), are usually accompanied by major changes in mafic phenocryst abundances (see also Robinson et al., this volume). All phenocryst phases show significant variability in abundance even within single cooling units.

Plagioclase occurs both as individual, mostly euhedral phenocrysts up to several millimeters in size, and as glomerocrysts with clinopyroxene and minor olivine. Glomerocrysts form "bow-ties" or subophitic, often gabbroic, glomerocrysts. In Hole 418A, plagioclase composition ranges from $\mathrm{Ab}_{54}$ in a phenocryst rim to $\mathrm{Ab} 9.3$ in the center of a phenocryst in the most maficmelts in unit $\mathrm{C}$ as defined by Byerly and Sinton (this volume). Most phenocryst interiors, however, vary from roughly $\mathrm{Ab}_{14}$ to $\mathrm{Ab}_{24}$ (averages given in Table 4). Even though single crystals can vary by $25 \mathrm{~mol}$. per cent Ab, there is a rough correlation of plagioclase composition with liquid composition (high in $\mathrm{Ab}$ in high-TiO 2 liquids) and cooling rate (higher $\mathrm{Ab}$ in massive units). The amount of minor elements increases towards the rim of the phenocrysts, $\mathrm{FeO}$ and $\mathrm{Mg}$ being incorporated roughly in equal molar amounts (wt. $\% \mathrm{FeO}$ is approximately $2 \times$ wt. $\% \mathrm{MgO}$ ).

Olivine usually occurs as individual, euhedral phenocrysts $<1 \mathrm{~mm}$ in size. Fresh olivine occurs throughout Hole

TABLE 2

Whole Rock Major Element and Trace Element Analyses, Hole 417D

$26-3,40 \quad 27-7,14 \quad 33-4,20 \quad 35-5,9 \quad 35-5,126 \quad 38-3,123 \quad 42-5,115 \quad 49-2,23 \quad 53-2,61 \quad 60-6,50 \quad 68-4,20 \quad 69-1,122$

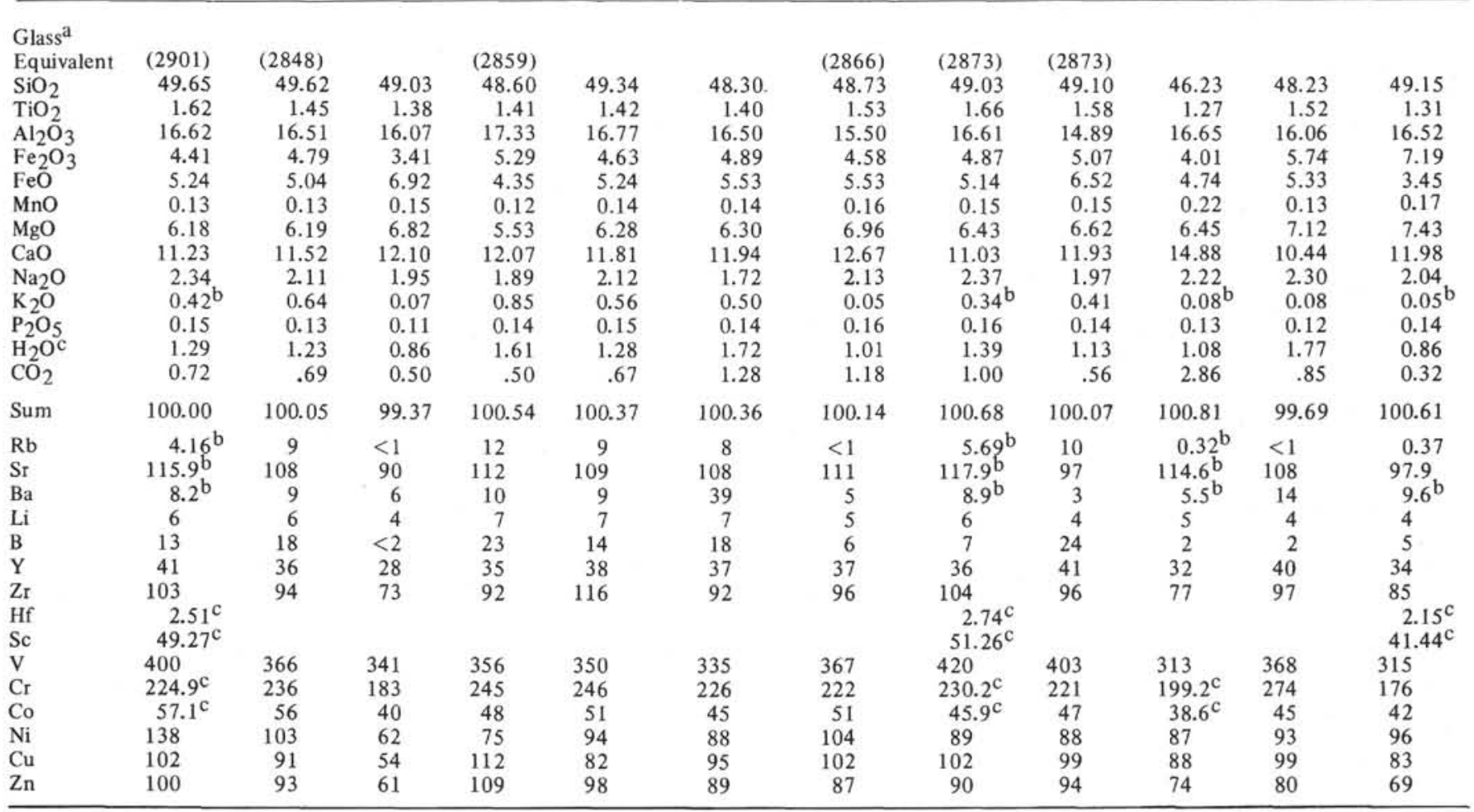

${ }^{\mathrm{a}}$ USNM number of corresponding glass (Byerly and Sinton, this volume).

$\mathrm{b}_{\text {Determined by IDMS. }}$

${ }^{\mathrm{c}}$ Determined by INAA. 
TABLE 3

Whole Rock Major Element and Trace Element Analyses, Hole 418A, Except as Indicated

$15-2,0 \quad 17-3,40 \quad 18-4,40 \quad 22-1,46 \quad 24-1,59 \quad 30-3,4 \quad 41-3,100 \quad 42-3,68 \quad 45-2,131 \quad 52-5,75 \quad 55-6,15 \quad 57-2,113$

\begin{tabular}{|c|c|c|c|c|c|c|c|c|c|c|c|c|}
\hline Glass $^{\mathrm{a}}$ & & & & & & & & & & & & \\
\hline Equivalent & $(3040)$ & & & & & (2939) & & (3041) & & $(3021)$ & $(3020)$ & (3025) \\
\hline $\mathrm{SiO}_{2}$ & 49.81 & 48.62 & 49.55 & 48.15 & 49.73 & 48.37 & 47.88 & 47.36 & 48.41 & 49.41 & 49.83 & 48.37 \\
\hline $\mathrm{TiO}_{2}^{2}$ & 1.20 & 1.22 & 1.13 & 1.13 & 1.22 & 1.23 & 1.13 & .99 & 1.05 & 1.12 & 1.30 & 1.40 \\
\hline $\mathrm{Al}_{2} \mathrm{O}_{3}$ & 17.48 & 17.23 & 16.57 & 15.98 & 17.45 & 16.24 & 16.49 & 17.29 & 17.28 & 16.77 & 15.34 & 16.90 \\
\hline $\mathrm{Fe}_{2} \mathrm{O}_{3}$ & 3.88 & 3.51 & 3.82 & 3.87 & 4.68 & 4.29 & 4.91 & 3.82 & 3.51 & 4.22 & 4.17 & 3.71 \\
\hline $\mathrm{FeO}$ & 4.84 & 4.64 & 5.63 & 5.14 & 4.15 & 5.24 & 4.25 & 4.54 & 4.94 & 5.33 & 6.32 & 6.22 \\
\hline $\mathrm{MnO}$ & 0.11 & 0.14 & 0.16 & 0.16 & 0.09 & 0.18 & 0.18 & 0.11 & 0.15 & 0.15 & 0.18 & 0.13 \\
\hline $\mathrm{MgO}$ & 6.76 & 7.09 & 7.55 & 7.27 & $5: 69$ & 7.24 & 5.93 & 6.57 & 7.17 & 6.78 & 7.69 & 5.45 \\
\hline $\mathrm{CaO}$ & 11.57 & 12.74 & 12.41 & 12.64 & 11.66 & 12.62 & 13.16 & 12.15 & 13.04 & 12.68 & 12.28 & 12.89 \\
\hline $\mathrm{Na}_{2} \mathrm{O}$ & 2.53 & 2.58 & 1.80 & 2.47 & 2.86 & 1.89 & 2.15 & 2.39 & 2.03 & 1.80 & 2.22 & 2.08 \\
\hline $\mathrm{K}_{2} \mathrm{O}$ & $0.34^{b}$ & $0.14^{b}$ & $0.05^{b}$ & 0.03 & 0.29 & 0.15 & $1.33^{\mathrm{b}}$ & $0.21^{\mathrm{b}}$ & 0.15 & 0.13 & 0.07 & 0.12 \\
\hline $\mathrm{P}_{2} \mathrm{O}_{5}$ & 0.14 & 0.14 & 0.13 & 0.14 & 0.13 & 0.14 & 0.13 & 0.09 & 0.11 & 0.12 & 0.14 & 0.09 \\
\hline $\mathrm{H}_{2} \mathrm{O}^{\mathrm{c}}$ & 1.18 & 1.13 & 0.76 & 1.02 & 1.39 & 0.89 & 1.54 & 1.30 & 1.26 & 1.09 & 0.72 & 1.08 \\
\hline $\mathrm{CO}_{2}$ & 0.54 & 1.21 & 0.45 & 0.97 & 0.64 & 0.81 & 1.59 & 0.55 & 1.36 & 0.58 & 0.41 & 0.61 \\
\hline Sum & 100.38 & 100.06 & 100.35 & 100.38 & 99.98 & 99.26 & 100.74 & 100.16 & 100.46 & 100.18 & 100.75 & 99.05 \\
\hline $\mathrm{Rb}$ & $3.02^{b}$ & $1.33^{b}$ & $0.41^{b}$ & 1 & 4 & 3.5 & $9.48^{b}$ & $2.31^{b}$ & 2 & 3 & $<1$ & $2.96^{\mathrm{b}}$ \\
\hline $\mathrm{Sr}$ & $114.0^{\mathrm{b}}$ & $120.9^{\mathrm{b}}$ & $110.7^{\mathrm{b}}$ & 113 & 117 & 106 & $376.2^{\mathrm{b}}$ & $116.5^{b}$ & 106 & 103 & 105 & $105.7^{b}$ \\
\hline $\mathrm{Ba}$ & $10.9^{b}$ & $13.9^{b}$ & $7.1^{b}$ & 5 & 7 & 4 & $5.6^{b}$ & 4 & 6 & 4 & 5 & $7.5^{b}$ \\
\hline $\mathrm{Li}$ & 5 & 7 & 4 & 8 & 4 & 3 & 7 & 5 & 5 & 4 & 5 & 6 \\
\hline B & 19 & 31 & 14 & 46 & 19 & 49 & 79 & 3 & 38 & 8 & 2 & 8 \\
\hline $\mathrm{Y}$ & 30 & 28 & 29 & 28 & 30 & 32 & 33 & 25 & 29 & 31 & 34 & 36 \\
\hline $\mathrm{Zr}_{\mathrm{r}}$ & 78 & 75 & 73 & 73 & 78 & 78 & 67 & 64 & 70 & 73 & 83 & 87 \\
\hline $\mathrm{Hf}$ & $1.83^{\mathrm{c}}$ & & & $1.88^{\mathrm{C}}$ & & & & $1.60^{\mathrm{c}}$ & & & & $2.17^{\mathrm{c}}$ \\
\hline $\mathrm{Sc}$ & $46.01^{c}$ & & & $46.20^{\mathrm{C}}$ & & & & $47.00^{c}$ & & & & $44.49^{c}$ \\
\hline V & 321 & 319 & 295 & 302 & 326 & 325 & 303 & 268 & 293 & 299 & 336 & 353 \\
\hline $\mathrm{Cr}$ & $212.2^{\mathrm{c}}$ & 223 & 212 & $249.3^{c}$ & 248 & 264 & 294 & $346.3^{c}$ & 319 & 292 & 280 & $216.4^{c}$ \\
\hline Co & $43.7^{\mathrm{c}}$ & 58 & 41 & $41.6^{\mathrm{c}}$ & 69 & 49 & 50 & $42.7^{\mathrm{c}}$ & 52 & 50 & 48 & $42.3^{\mathrm{c}}$ \\
\hline $\mathrm{Ni}$ & 94 & 97 & 76 & 83 & 95 & 107 & 115 & 125 & 136 & 131 & 110 & 89 \\
\hline $\mathrm{Cu}$ & 99 & 104 & 102 & 97 & 106 & 99 & 98 & 93 & 98 & 102 & 107 & 93 \\
\hline $\mathrm{Zn}$ & 81 & 73 & 60 & 68 & 68 & 81 & 73 & 63 & 68 & 72 & 80 & 80 \\
\hline
\end{tabular}

${ }^{a}$ USNM number of corresponding glass (Byerly and Sinton, this volume).

betermined by IDMS.

${ }^{\mathrm{c}}$ Determined by INAA.

418A, mostly in glassy selvages. In crystalline interiors of individual cooling units olivine is usually replaced by smectite and/or carbonate. Olivine shows a limited compositional range from $\mathrm{Fo}_{82}$ to $\mathrm{Fos}_{8}$. The olivine composition is clearly related to the corresponding composition (Fo-content decreases with $\mathrm{TiO}_{2}$ of glass). Single olivine crystals are very homogeneous. An average analysis is given in Table 4.

Clinopyroxene occurs mostly as subhedral individual phenocrysts up to roughly $1 \mathrm{~mm}$ in size in subophitic glomerocrysts. Euhedral, often nearly spherical xenocrysts are common and are up to several millimeters in size. Clinopyroxene phenocrysts are usually zoned, e.g., En 41 $\mathrm{Fs}_{25} \mathrm{Wo}_{44}$ (rim) - En ${ }_{7} \mathrm{FS}_{17} \mathrm{Wo}_{36}$ (center). An analyzed xenocryst is comparatively homogeneous (En ${ }_{51}$ Fs8 $_{8}$ Wo41 $_{4}$ - En54 Fs59 Wo38). Average analyses are given in Table 4.

\section{CHEMICAL VARIATION IN HOLES 417D AND 418A}

Our major and trace element data for whole rock basalt samples are presented in Tables 2 and 3. Similar to the plots presented by Bryan and Flower (this volume) and Flower and Bryan (this volume) for the shipboard chemical analyses, we have plotted some critical major element parameters in Figures 1 and 2. Comparison with the shipboard analyses indicate that our data cover most of the known range of variation at Holes 417D and 418A and no exceptional analyses have been found. There is considerable overlap of major and trace element abundances, and no distinct grouping is encountered.

Plots of $\mathrm{Y}$ versus $\mathrm{Zr}$ (Figure 3 ) or $\mathrm{Zr}$ versus $\mathrm{TiO}_{2}$ (Figure 4) show strong correlation and similarity between the two sites. These are elements insensitive to weathering (Thompson, 1973) and, being incompatible elements, i.e., preferably partitioned into the liquid phase, their ratios are not significantly affected by crystal accumulation or fractional crystallization. The $\mathrm{Y} / \mathrm{Zr}$ ratio is relatively constant and the data plot on a straight line passing through the origin (Figure 3). Other incompatible elements like Ti, V and REE (Staudigel et al., this volume) also show relatively constant ratios. This suggests a similar homogeneous source region for the baslats from both sites.

Figure 5 shows a plot of $\mathrm{Ni}$ versus $\mathrm{TiO}_{2}$ for the two sites. The variability of the glass data (Byerly and Sinton, this volume) suggests fractional crystallization up to 34 per cent, always including olivine (up to $5.4 \%$ ). Because $\mathrm{Ni}$ is preferentially partitioned into olivine, increasing fractionation (indicated by increasing $\mathrm{TiO}_{2}$ content) should be accompanied by decreasing $\mathrm{Ni}$. This trend shows considerable scatter, as seen in Figure 5, which may reflect crystal accumulation or redistribution.

The trace elements $\mathrm{B}, \mathrm{Li}, \mathrm{Rb}$, and occasionally $\mathrm{Sr}$ and $\mathrm{Ba}$, show variability reflecting low temperature alteration 
TABLE 3 - Continued

\begin{tabular}{|c|c|c|c|c|c|c|c|c|c|c|c|c|}
\hline $60-5,133$ & $62-4,104$ & $64-4,82$ & $69-3,63$ & $73-1,127$ & $76-1,4$ & $76-2,99$ & $77-2,47$ & $\begin{array}{c}79-4,88 \\
\text { (Dike) }\end{array}$ & $79-4,88$ & $80-2,123$ & $86-5,29$ & $\begin{array}{l}418 \mathrm{~B}- \\
35-5,78\end{array}$ \\
\hline & (3047) & (3049) & (3051) & (3029) & $(3027)$ & & & $(3052)$ & & & (3032) & (3035) \\
\hline 48.03 & 49.50 & 48.46 & 48.70 & 49.55 & 49.39 & 46.66 & 48.31 & 49.22 & 48.84 & 49.85 & 48.76 & 50.67 \\
\hline 1.48 & 1.56 & 1.29 & 1.26 & 1.28 & 1.29 & 1.00 & 1.29 & 1.21 & 1.23 & 1.24 & 1.17 & 1.24 \\
\hline 15.74 & 15.91 & 16.14 & 16.47 & 15.94 & 16.30 & 14.92 & 14.99 & 15.08 & 15.96 & 16.10 & 17.15 & 17.36 \\
\hline 4.72 & 3.93 & 3.87 & 3.84 & 3.99 & 4.17 & 4.40 & 4.18 & n.d. & 3.46 & 3.72 & 4.21 & 3.88 \\
\hline 5.83 & 6.62 & 5.63 & 6.22 & 6.03 & 5.43 & 3.56 & 5.53 & 9.57 & 5.63 & 6.32 & 5.14 & 4.25 \\
\hline 0.15 & 0.17 & 0.16 & 0.17 & 0.17 & 0.16 & 0.13 & 0.18 & 0.16 & 0.17 & 0.17 & 0.14 & 0.09 \\
\hline 6.05 & 6.84 & 6.18 & 7.25 & 7.76 & 7.59 & 6.92 & 6.92 & 7.40 & 6.50 & 7.18 & 5.78 & 6.01 \\
\hline 1263 & 12.04 & 13.86 & 12.60 & 12.40 & 11.91 & 15.29 & 14.04 & 12.98 & 13.55 & 12.83 & 13.54 & 11.29 \\
\hline 2.31 & 1.92 & 2.35 & 1.86 & 2.03 & 2.36 & 2.25 & 1.76 & 1.70 & 2.17 & 1.73 & 2.08 & 2.44 \\
\hline 0.03 & $0.22^{b}$ & $0.07^{b}$ & $0.12^{\mathrm{b}}$ & 0.06 & $0.23^{b}$ & $0.10^{\mathrm{b}}$ & 0.01 & 0.24 & 0.03 & 0.01 & $0.07^{b}$ & 0.88 \\
\hline 0.09 & 0.16 & 0.15 & 0.12 & 0.14 & 0.14 & 0.13 & 0.16 & 0.15 & 0.14 & 0.12 & 0.13 & 0.12 \\
\hline 0.94 & 1.03 & 0.95 & 0.92 & 0.79 & 1.20 & 0.95 & 0.64 & 1.08 & 0.62 & 0.76 & 1.10 & 1.27 \\
\hline 0.97 & 0.68 & 1.25 & 0.49 & 0.42 & 0.54 & 3.09 & 2.41 & 1.26 & 1.24 & 0.46 & 0.86 & 0.66 \\
\hline 98.95 & 100.55 & 100.33 & 99.92 & 100.56 & 100.68 & 99.38 & 100.42 & 100.05 & 99.59 & 100.49 & 100.13 & 100.16 \\
\hline$<1$ & $3.84^{b}$ & $1.45^{b}$ & $1.56^{\mathrm{b}}$ & $<1$ & $1.45^{b}$ & $2.55^{\mathrm{b}}$ & $<1$ & $<1$ & 1 & $<1$ & $1.07^{\mathrm{b}}$ & 7 \\
\hline 126 & $116.5^{\mathrm{b}}$ & $112.5^{\mathrm{b}}$ & $109.1^{\mathrm{b}}$ & 105 & $122.1^{b}$ & $127.4^{b}$ & 129 & 117 & 109 & 99 & $107.8^{\mathrm{b}}$ & 115 \\
\hline 6 & $11.5^{\mathrm{b}}$ & $7.9 \mathrm{~b}$ & $16.9^{\mathrm{b}}$ & 6 & 8 & 5 & 8 & 11 & 6 & 2 & $5.8^{\mathrm{b}}$ & 11 \\
\hline 4 & 5 & 5 & 1 & 2 & 2 & 4 & 2 & 1 & 3 & 1 & 1 & 7 \\
\hline 46 & 8 & 29 & 2 & $<2$ & $<2$ & 4 & $<2$ & 9 & $<2$ & $<2$ & $<2$ & 14 \\
\hline 38 & 40 & 33 & 33 & 33 & 33 & 28 & 33 & 31 & 32 & 31 & 30 & 29 \\
\hline 97 & $\begin{array}{l}102 \\
2.51^{\mathrm{c}}\end{array}$ & 85 & 84 & $\begin{array}{l}81 \\
2.16^{\mathrm{c}} \\
46.04^{\mathrm{c}}\end{array}$ & 84 & $\begin{array}{l}67 \\
1.40^{\mathrm{c}} \\
43.16^{\mathrm{c}}\end{array}$ & 86 & 80 & 78 & $\begin{array}{l}78 \\
1.98^{\mathrm{c}} \\
44.87^{\mathrm{c}}\end{array}$ & $\begin{array}{l}77 \\
1.69^{\mathrm{c}} \\
43.62^{\mathrm{c}}\end{array}$ & 80 \\
\hline & $45.95^{\mathrm{c}}$ & & 327 & $\begin{array}{l}46.04^{c} \\
338\end{array}$ & 337 & $43.16^{\mathrm{c}}$ & 334 & 319 & 315 & $\begin{array}{l}44.87^{\mathrm{c}} \\
320\end{array}$ & $43.62^{\mathrm{c}}$ & 331 \\
\hline $\begin{array}{l}364 \\
192\end{array}$ & $\begin{array}{l}385 \\
209.7^{\mathrm{c}}\end{array}$ & $\begin{array}{l}340 \\
183\end{array}$ & 222 & $\begin{array}{l}338 \\
230.6^{\mathrm{c}}\end{array}$ & $\begin{array}{l}337 \\
198\end{array}$ & $\begin{array}{l}281 \\
259.7^{\mathrm{c}}\end{array}$ & $\begin{array}{l}334 \\
154\end{array}$ & $\begin{array}{l}319 \\
259\end{array}$ & 181 & $\begin{array}{l}320 \\
270.2^{\mathrm{c}}\end{array}$ & $\begin{array}{l}316 \\
304.5^{c}\end{array}$ & $\begin{array}{l}331 \\
244\end{array}$ \\
\hline 45 & $44.9^{\mathrm{c}}$ & 48 & 47 & $43.6^{\mathrm{c}}$ & $\begin{array}{r}190 \\
46\end{array}$ & $41.2^{\mathrm{c}}$ & 44 & 47 & 41 & $48.3^{\mathrm{C}}$ & $43.7^{\mathrm{c}}$ & 59 \\
\hline 86 & 93 & 79 & 90 & 85 & 78 & 123 & 81 & 101 & 65 & 91 & 118 & 98 \\
\hline 92 & 94 & 104 & 84 & 90 & 89 & 99 & 100 & 94 & 84 & 95 & 96 & 99 \\
\hline 79 & 93 & 82 & 76 & 78 & 83 & 57 & 70 & 71 & 64 & 70 & 73 & 82 \\
\hline
\end{tabular}

TABLE 4

Average Mineral Compositions in Site 418 Basalts

\begin{tabular}{|c|c|c|c|c|c|}
\hline & \multirow[t]{2}{*}{ Olivine $^{\mathrm{a}}$} & \multicolumn{2}{|c|}{ Clinopyroxene } & \multicolumn{2}{|c|}{ Plagioclase } \\
\hline & & Phenocryst & Xenocryst & $\mathrm{Ab} \overline{14^{\mathrm{a}}}$ & $\mathrm{Ab} 24$ \\
\hline & $12^{\mathrm{b}}$ & $18^{\mathrm{b}}$ & $10^{\mathrm{b}}$ & $18^{\mathrm{b}}$ & $12^{\mathrm{b}}$ \\
\hline $\mathrm{SiO}_{2}$ & 38.54 & 51.50 & 52.80 & 46.94 & 49.03 \\
\hline $\mathrm{TiO}_{2}^{2}$ & 0.07 & 0.55 & 0.32 & 0.02 & 0.02 \\
\hline $\mathrm{Al}_{2} \mathrm{O}_{3}$ & 0.09 & 3.38 & 2.66 & 33.30 & 31.61 \\
\hline $\mathrm{FeO}^{3}$ & 15.06 & 7.23 & 5.40 & 0.43 & 0.44 \\
\hline $\mathrm{MgO}$ & 45.74 & 17.09 & 18.56 & 0.21 & 0.28 \\
\hline $\mathrm{MnO}$ & 0.27 & 0.19 & 0.18 & 0.01 & 0.05 \\
\hline $\mathrm{CaO}$ & 0.38 & 19.28 & 19.48 & 17.20 & 15.35 \\
\hline $\mathrm{Na}_{2} \mathrm{O}$ & 0.01 & 0.22 & 0.24 & 1.59 & 2.63 \\
\hline $\mathrm{K}_{2} \mathrm{O}$ & 0.00 & 0.00 & 0.00 & 0.01 & 0.02 \\
\hline $\mathrm{Cr}_{2}^{2} \mathrm{O}_{3}$ & 0.07 & 0.37 & 0.68 & 0.02 & 0.01 \\
\hline Sum & 100.23 & 99.81 & 100.32 & 99.73 & 99.44 \\
\hline
\end{tabular}

${ }^{a}$ Compositions used for least-squares calculations.

${ }^{\mathrm{b}}$ Number of averaged analyses.

processes. They are generally positively correlated with increasing $\mathrm{K}_{2} \mathrm{O}, \mathrm{H}_{2} \mathrm{O}$, and $\mathrm{Fe}_{2} \mathrm{O}_{3} / \mathrm{FeO}$ as would be expected with increasing alteration.

In Tables 5A and 5B, we show average compositions for some trace elements based on $\mathrm{TiO}_{2}$ contents. In general, particularly in Hole 418A, the role of fractional crystallization in explaining the ranges is clearly documented. Incompatible elements such as $\mathrm{Sr}, \mathrm{Y}, \mathrm{Zr}, \mathrm{V}$, and $\mathrm{Zn}$ show increasing concentration with increasing $\mathrm{TiO}_{2}$ in both sites. Compatible elements such as $\mathrm{Cr}, \mathrm{Ni}$, and $\mathrm{Cu}$ apparently

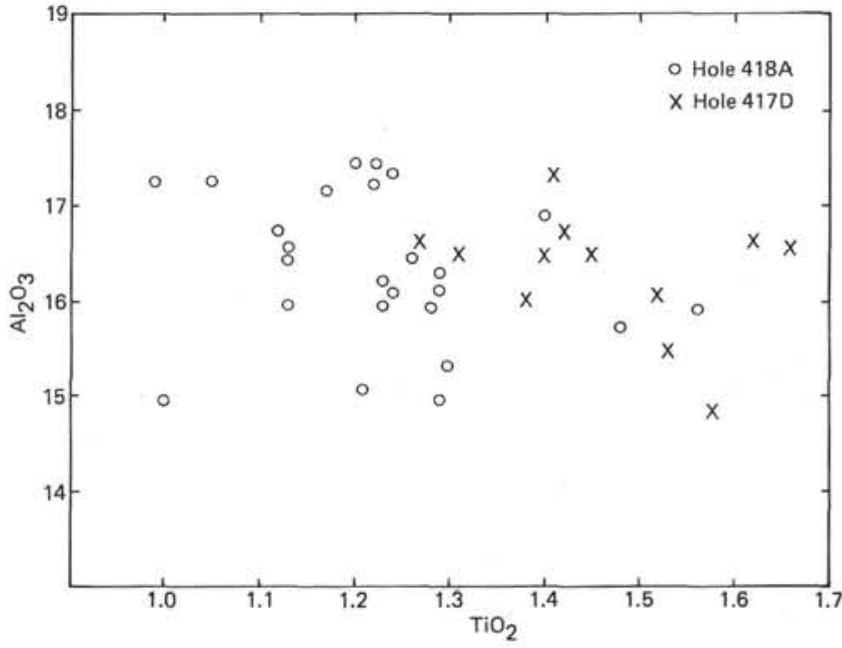

Figure 1. $\mathrm{Al}_{2} \mathrm{O}_{3}$ vs. $\mathrm{TiO}_{2}$ in Holes $417 \mathrm{D}$ and $418 \mathrm{~A}$ whole rocks.

show decreasing concentrations with increasing $\mathrm{TiO}_{2}$ in Hole 418A. This correlation is reversed as seen in Hole 417D where the compatible elements show relatively high concentrations at higher $\mathrm{TiO}_{2}$ contents, this effect possibly being due to crystal accumulation as discussed in a later section.

Although no obvious chemical groupings or differences are readily detectable between the two sites or within a given site, there are no simple systematic trends from top to 


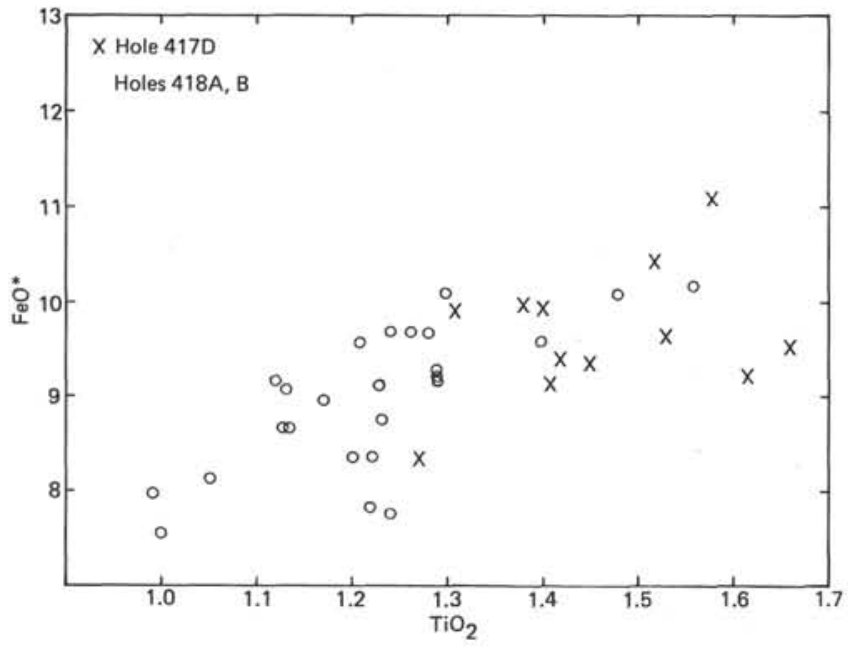

Figure 2. $\mathrm{FeO}$ vs. $\mathrm{TiO}_{2}$ in Holes $417 \mathrm{D}$ and $418 \mathrm{~A}$ whole rocks.

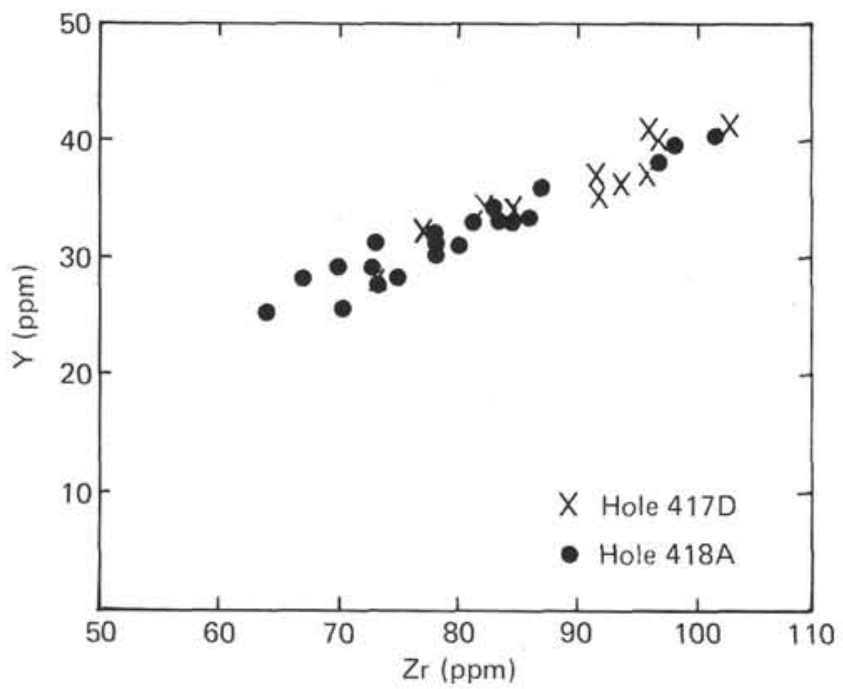

Figure 3. $Y$ vs. $\mathrm{Zr}$ in Holes $417 \mathrm{D}$ and $418 \mathrm{~A}$ whole rocks.

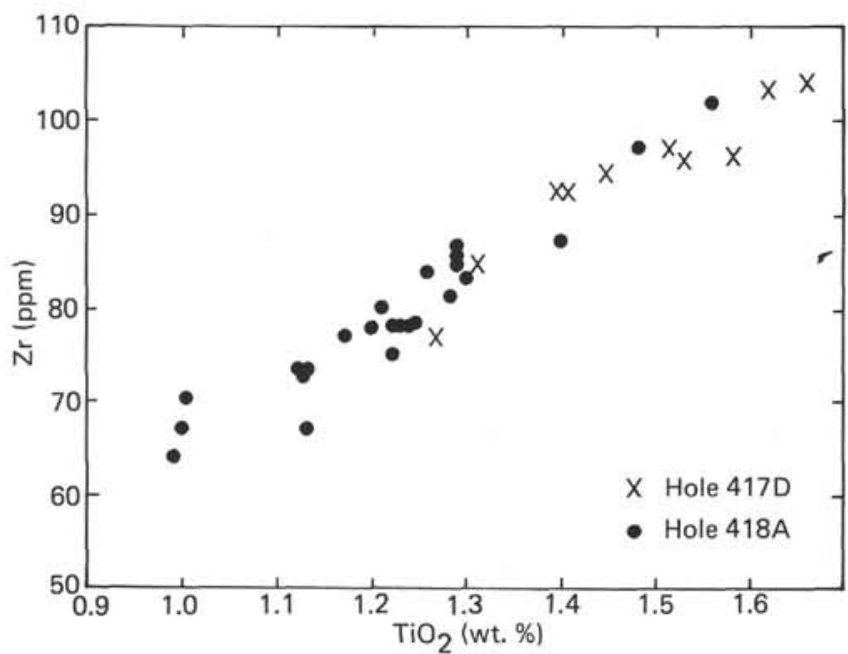

Figure 4. $\mathrm{Zr}$ vs. $\mathrm{TiO}_{2}$ in Holes $417 \mathrm{D}$ and $418 \mathrm{~A}$ whole rocks.

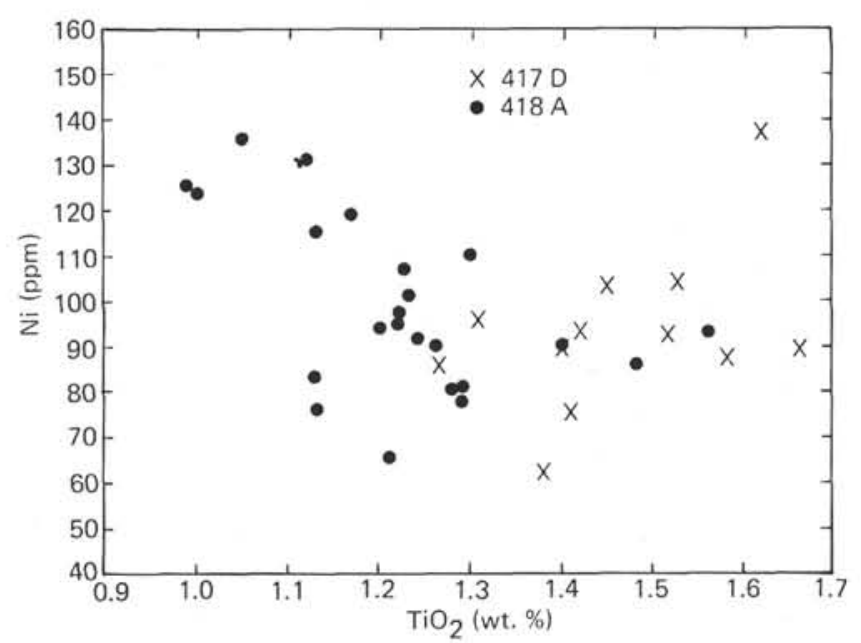

Figure 5. $\mathrm{Ni}$ vs. $\mathrm{TiO}_{2}$ in Holes $417 \mathrm{D}$ and $418 \mathrm{~A}$ whole rocks.

TABLE 5A

Average Trace Element Compositions of Hole 417D Basalts Grouped by $\mathrm{TiO}_{2}$ Contents

\begin{tabular}{lccc}
\hline & $\begin{array}{c}1.2-1.4 \% \mathrm{TiO}_{2} \\
(\mathrm{~N}=3)\end{array}$ & $\begin{array}{c}1.4-1.6 \% \mathrm{TiO}_{2} \\
(\mathrm{~N}=7)\end{array}$ & $\begin{array}{c}1.6-1.8 \% \mathrm{TiO}_{2} \\
(\mathrm{~N}=2)\end{array}$ \\
\hline $\mathrm{Sr}$ & 101 & 108 & 117 \\
$\mathrm{Y}$ & 31 & 38 & 39 \\
$\mathrm{Zr}$ & 78 & 97 & 104 \\
$\mathrm{~V}$ & 323 & 364 & 410 \\
$\mathrm{Zn}$ & 68 & 93 & 95 \\
$\mathrm{Cr}$ & 186 & 239 & 228 \\
$\mathrm{Ni}$ & 82 & 92 & 114 \\
$\mathrm{Cu}$ & 75 & 97 & 102 \\
\hline
\end{tabular}

TABLE 5B

Average Trace Element Compositions of Hole 418A Basalts Grouped by $\mathrm{TiO}_{2}$ Contents

\begin{tabular}{lccr}
\hline & $\begin{array}{c}<1.2 \% \mathrm{TiO}_{2} \\
(\mathrm{~N}=8)\end{array}$ & $\begin{array}{c}1.2-1.4 \% \mathrm{TiO}_{2} \\
(\mathrm{~N}=13)\end{array}$ & $\begin{array}{r}>1.4 \% \mathrm{TiO}_{2} \\
(\mathrm{~N}=3)\end{array}$ \\
\hline $\mathrm{Sr}$ & 112 & 113 & 116 \\
$\mathrm{Y}$ & 29 & 32 & 38 \\
$\mathrm{Zr}$ & 71 & 81 & 95 \\
$\mathrm{~V}$ & 295 & 327 & 367 \\
$\mathrm{Zn}$ & 67 & 75 & 84 \\
$\mathrm{Cr}$ & 285 & 225 & 206 \\
$\mathrm{Ni}$ & 113 & 90 & 89 \\
$\mathrm{Cu}$ & 98 & 96 & 93 \\
\hline
\end{tabular}

bottom in either hole. Chemical groupings are recognized only according to stratigraphic entities or cooling units. In Table $5 \mathrm{C}$ we show averages for the trace element contents of various such units recognized by Byerly and Sinton (this volume) and Robinson et al. (this volume) and based on glass chemistry and lithology in Hole $418 \mathrm{~A}$ basalts. In the upper part of Hole 418A (glass groups A-F) the incompatible elements of our whole rock analyses show typical low pressure fractionation characteristics, e.g., high $\mathrm{Sr}, \mathrm{Y}, \mathrm{Zr}, \mathrm{V}$, and $\mathrm{Zn}$ at high $\mathrm{Ti}, \mathrm{FeO} / \mathrm{MgO}$. The compatible elements show a less systematic behavior which might re- 
TABLE 5C

Average Trace Element Composition of Site 418A Basalts Grouped Stratigraphically and by Previously Recognized Chemical Units

\begin{tabular}{|c|c|c|c|c|c|c|c|c|}
\hline Glass group ${ }^{a}$ & A, B & $C-E$ & H & 1 & J & & & \\
\hline Chemical group ${ }^{b}$ & 1 & II & III & IV & V & VI & VII & VIII \\
\hline Number of samples & $(\mathrm{N}=7)$ & $(\mathrm{N}=3)$ & $(\mathrm{N}=3)$ & $(\mathrm{N}=1)$ & $(\mathrm{N}=2)$ & $(\mathrm{N}=5)$ & $(\mathrm{N}=1)$ & $(\mathrm{N}=1)$ \\
\hline Sr & 114 & 108 & 116 & 113 & 107 & 121 & 99 & 108 \\
\hline $\mathrm{Y}$ & 30 & 28 & 38 & 33 & 33 & 31 & 31 & 30 \\
\hline $\mathrm{Zr}_{\mathrm{r}}$ & 75 & 69 & 95 & 85 & 82 & 79 & 78 & 77 \\
\hline v & 313 & 287 & 367 & 340 & 332 & 317 & 320 & 316 \\
\hline $\mathrm{Zn}$ & 71 & 68 & 84 & 82 & 77 & 69 & 70 & 73 \\
\hline $\mathrm{Cr}$ & 243 & 319 & 206 & 183 & 222 & 210 & 270 & 305 \\
\hline $\mathrm{Ni}$ & 95 & 131 & 89 & 79 & 87 & 90 & 91 & 118 \\
\hline $\mathrm{Cu}$ & 101 & 98 & 93 & 104 & 87 & 93 & 95 & 96 \\
\hline
\end{tabular}

${ }^{a}$ Byerly and Sinton (this volume)

b Robinson et al. (this volume).

flect the influence of crystal accumulation. The complex interdigitation of these various compositions must reflect a complex tapping of a single magma at various stages of fractionation and/or refilling of the magma chamber, or tapping of two separate magmas at different stages of fractionation. If two magmas are invoked, our chemical data would suggest they are derived from the same or very similar mantle sources.

The relatively low $\mathrm{Rb}, \mathrm{Ba}, \mathrm{Sr}, \mathrm{Y}$, and $\mathrm{Zr}$ contents confirm the rare earth evidence presented by Staudigel et al. (this volume), indicating that these basalts are typical large ion lithophile (LIL) element depleted mid-ocean ridge basalts. The present ridge axis at $22^{\circ} \mathrm{N}$ is similarly LIL element depleted (Melson et al., 1968; Bryan and Sargent, 1979). Thus it appears that the influence of the Azores "plume" or "blob" (Schilling, 1975) presently seen on the Mid-Atlantic Ridge axis from $37^{\circ}$ to $30^{\circ} \mathrm{N}$ latitude did not extend to the ridge at $22^{\circ} \mathrm{N}$ during Cretaceous time. Indeed, data from DSDP Site 335, Leg 37 (Bryan and Thompson, 1977) suggest that the Azores plume activity was not present 15 million years ago even at $36^{\circ} \mathrm{N}$ latitude.

\section{COMPARISON OF GLASS-WHOLE ROCK COMPOSITIONS}

Our analyzed whole rock samples have been selected so that in most cases they are physically within a few centimeters of the analyzed glasses. Thus, there is no doubt that these samples represent identical magmas. Subtle variations which might be produced, for example, by successive injections of different magmas through a lava tube or into a sill, are therefore most likely excluded in this data set. Assuming that all samples are perfectly fresh and unmodified by interaction with sea water, and that no systematic instrumental differences exist between the microprobe and X-ray fluorescence analytical methods, the only compositional differences which should exist are those reflecting the phenocryst assemblage included in the whole rock analysis, or those small changes that might result from fine-scale inhomogeneity in the rock. Unfortunately, the selective sampling close to glass margins results in the inclusion of palagonitized glass in many samples, and many of the crystalline rock samples are affected to some extent by submarine low temperature alteration and the precipitation of secondary $\mathrm{CaCO}_{3}$ (Donnelly et al., this volume). This is clearly seen in the covariance of elements such as $\mathrm{K}$, $\mathrm{B}, \mathrm{Li}$, and $\mathrm{Rb}$ with $\mathrm{H}_{2} \mathrm{O}$ content and $\mathrm{Fe}_{2} \mathrm{O}_{3} / \mathrm{FeO}$ ratio. The contents of $\mathrm{K}, \mathrm{H}_{2} \mathrm{O}$, and $\mathrm{Fe}_{2} \mathrm{O}_{3} / \mathrm{FeO}$ tend to be systematically higher in the whole rock analyses compared to glasses.

Following a practice adopted on shipboard as outlined in the site reports, we originally attempted to correct our analyses by subtracting an amount of $\mathrm{CaO}$ equal to that required to convert all $\mathrm{CO}_{2}$ to $\mathrm{CaCO}_{3}$ and, because all $\mathrm{Fe}$ is determined as $\mathrm{FeO}$ in the microprobe glass analyses, we converted all $\mathrm{Fe}_{2} \mathrm{O}_{3}$ to $\mathrm{FeO}$. However, we abandoned the carbonate correction because it appeared to over-correct for the addition of $\mathrm{CaO}$ as carbonate. We believe this occurs because $\mathrm{CaO}$ also is leached from the rock matrix during interaction with sea water. Thus, in more altered samples, the addition of $\mathrm{CaO}$ as carbonate veins partly or completely compensates for the loss of $\mathrm{CaO}$ in the rock matrix. Thus, we have recalculated the whole rock analyses to 100 per cent volatile-free, with all $\mathrm{Fe}$ as $\mathrm{FeO}$, but have made no adjustment in $\mathrm{CaO}$ other than that required by the normalization procedure. The microprobe analyses were normalized to 100 per cent only if they initially totaled 99 per cent or less or 101 per cent or more; otherwise the original summation was retained. These normalized whole rock and probe analyses have been used in the graphical plots (Figures 6 and 7) and calculations (Table 6).

Composition relations between glasses and their corresponding whole rock equivalents can be visualized in an $\mathrm{MgO}$ variation diagram (Figure 6) in which the corresponding glass-whole rock pairs are indicated by tie lines. Vectors drawn from two arbitrarily chosen points at either end of the data distribution show the trends to be expected from addition of plagioclase, pyroxene, or olivine. The tie lines fall into two categories - one in which all tie lines are approximately parallel to the plagioclase vector, leading to $\mathrm{MgO}$ depletion in whole rock relative to glass, and another group that appears to require a mixture of plagioclase and mafic phases and which leads to $\mathrm{MgO}$ enrichment in the whole rock relative to the glass. Both trends obviously lead the whole rock compositions away from the liquidus trends, as defined by the chemical variation of the glasses, indicating that the phenocryst distribution has been modified since the melt was extracted from the magma chamber. It is also shown in Figure 6 that phenocryst accumulation can modify the whole rock composition considerably. The difference between glass-whole rock can amount to more than the total range observed in glass compositions for $\mathrm{Si}, \mathrm{Mg}, \mathrm{Al}$, and $\mathrm{Ca}$, and to more than one-third for parameters like $\mathrm{Ti}$ or $\mathrm{Fe}$ (e.g., Sample 418A-79-4, $88 \mathrm{~cm}$ ).

Further insight into these relations is given by a plot of glass-whole rock pairs in the normative ternary plagioclase-pyroxene-olivine (Figure 7), in which the glasses lie along an apparent cotectic similar to that displayed by glasses from FAMOUS and most other DSDP sites (Bryan et al., 1976). The tie lines again fall into two general groups, one set projecting distinctly away from the cotectic into the plagioclase field, and the second set also projecting into the plagioclase field, but trending at a low angle to the cotectic. These trends suggest that whole rock compositions are the result of mixtures of liquid plus one of two populations of cumulate phenocryst assemblages, one consisting almost entirely of plagioclase and the second also dominated by plagioclase but with significant amounts of olivine or pyroxene. 


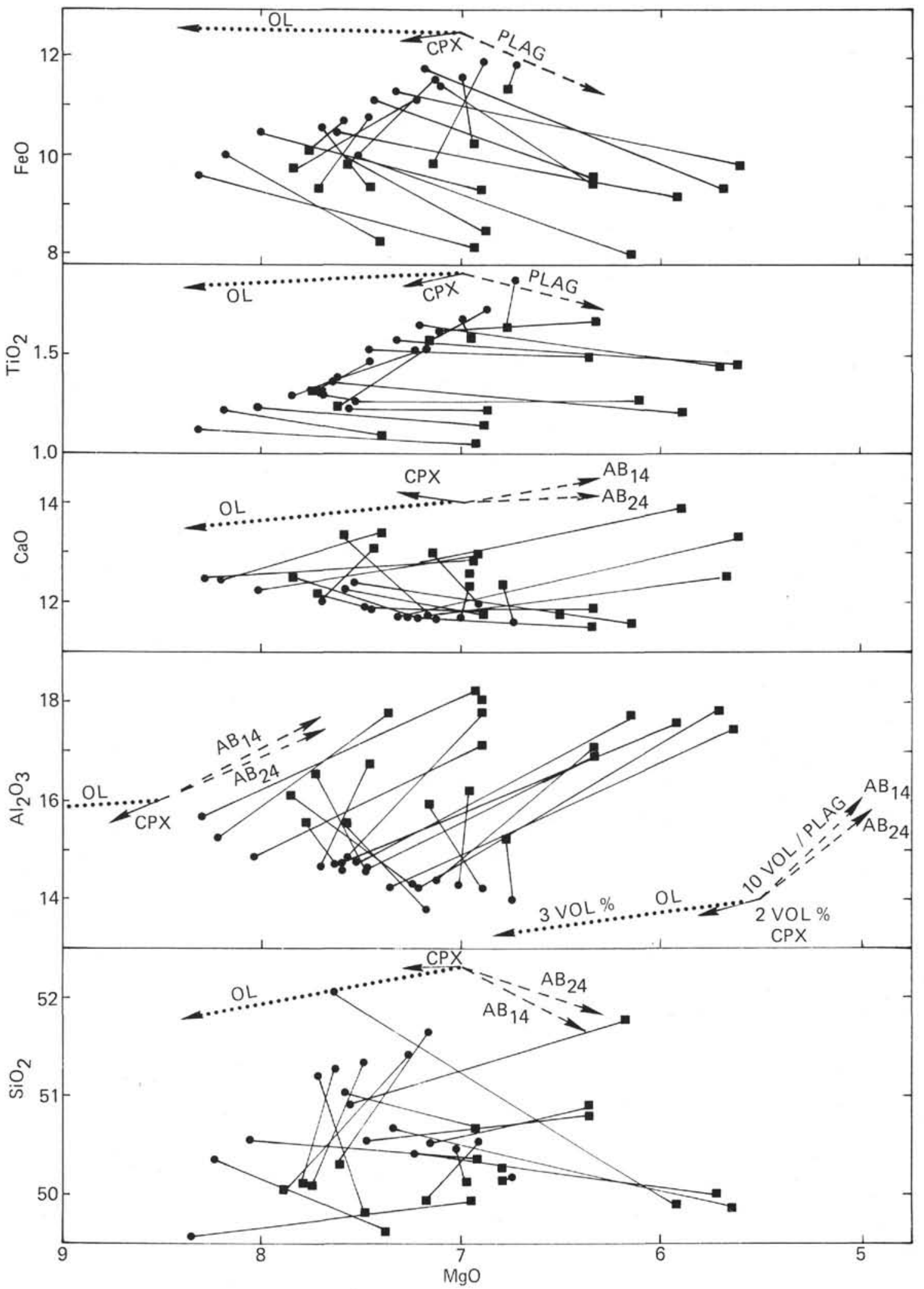

Figure 6. $\mathrm{MgO}$ variation diagram for glass-whole rock pairs from Holes $417 \mathrm{D}$ and $418 \mathrm{~A} . \bullet=$ glass analyses (Byerly and Sinton, this volume), and $\square=$ whole rock analyses. Corresponding glass-whole rock compositions are connected by tielines. Vectors indicate the effect of crystal accumulation of 3 vol. \% olivine (. . . line), 2 vol. \% clinopyroxene (_- line), and 10 vol. \% plagioclase (-- line). In the $\mathrm{CaO}, \mathrm{Al}_{2} \mathrm{O}_{3}$ and $\mathrm{SiO}_{2}$ diagrams, the plagioclase vectors are shown for two compositions $A b_{14}$ and $A b_{24}$. Mineral compositions are taken from Table 2. 


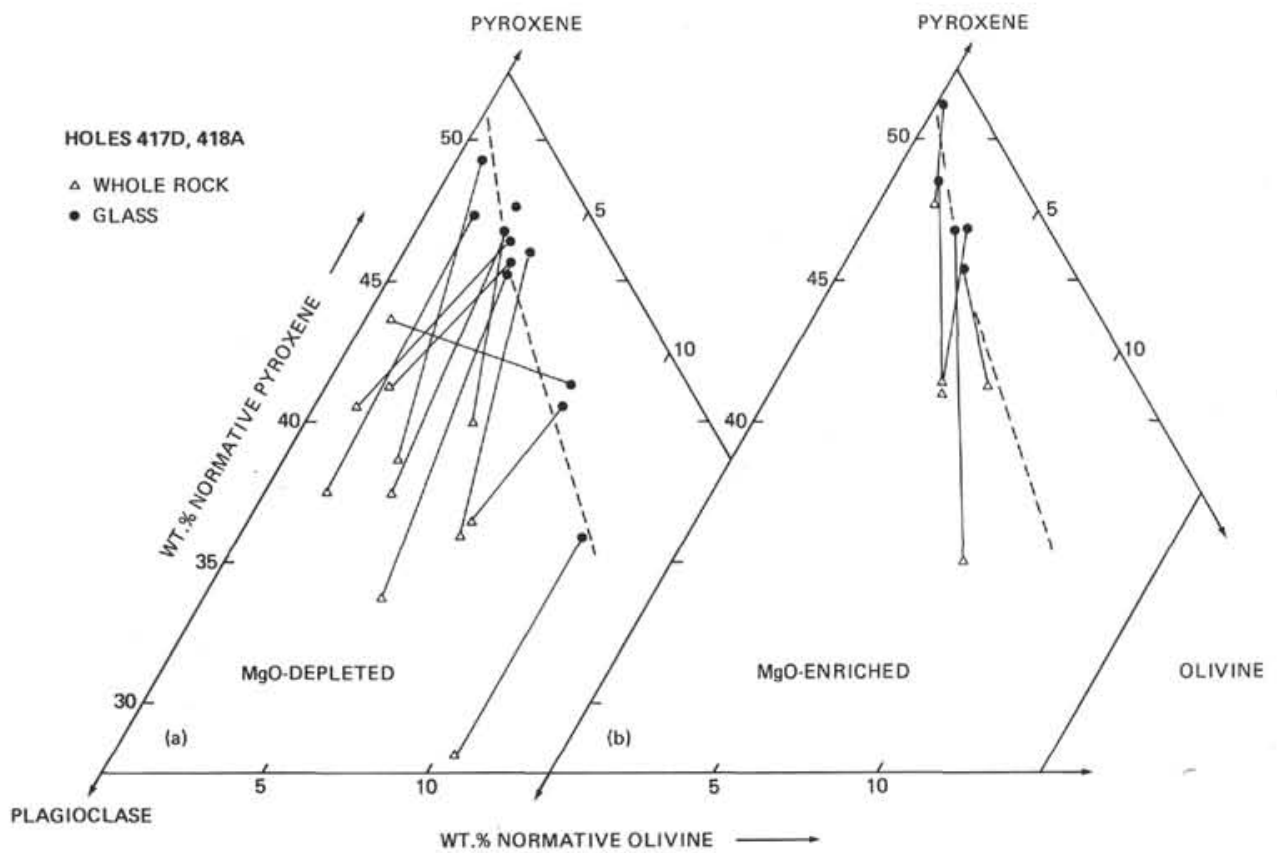

Figure 7. $(a, b)$. Ternary normative pyroxene-olivine-plagioclase plot for glasses $(\bullet)$ and corresponding whole-rock samples $(\Delta)$ from Holes $417 D$ and 418 A. Corresponding pairs are joined by tielines. (Pyroxene is total normative diopside, eustatite, and ferrosilite plus hypersthene.)

The phenocryst assemblage for each glass-whole rock pair was determined by modal analyses, and also theoretically calculated by least-squares mass balance calculations. Modal analyses were carried out using an automatic pointcounting stage. Usually 1500 counts gave representative analyses of an individual thin section, however, the phenocryst distribution can vary considerably even on thin section scale. The modal analyses for olivine and clinopyroxene are particularly biased by alteration effects and grain size, i.e., olivine is often weathered and replaced, and both olivine and clinopyroxene are generally smaller crystals than plagioclase and thus distinction from groundmass crystals is difficult. Modal data are given in column B of Table 6 in volume fractions while other data are in weight per cent. Considering those difficulties and biases, agreement between calculated and empirical "modes" are generally good. The most important point brought out in Table 6 is that both calculated and observed mineral assemblages are impoverished in pyroxene and olivine in the $\mathrm{MgO}$-depleted data sets, whereas significant amounts of these minerals occur in the phenocryst assemblages of the $\mathrm{MgO}$-enriched data sets.

$\mathrm{TiO}_{2}$ in whole rock analyses of plagioclase dominated$\mathrm{MgO}$ depleted trends is often slightly higher than plagioclase accumulation would suggest (Figure 6). This is often accompanied by an anomalously high $\mathrm{Fe}$ and $\mathrm{Cr}$ in the whole rock. Both effects probably indicate titanomagnetite accumulation, and this was observed in thin section in all such cases.

Because of the lack of trace element data for glasses, we are unable to demonstrate any convincing relationship between the nature and degree of phenocryst accumulation in these basalts, and the pattern of trace element enrichments or depletions in our whole rock analyses, although generally olivine-rich samples clearly have higher $\mathrm{Ni}$ and $\mathrm{Cr}$ contents. Lack of other significant trace element correlations probably reflects the dominance of plagioclase in all cumulate assemblages, but also must arise because these assemblages are added in varying proportions to liquids which themselves range over a considerable spectrum of compositions. A more rigorous evaluation of the effect of mineral cumulates on trace elements will thus require trace element analyses on specific glass samples. Also, in spite of the importance of plagioclase as a cumulate phenocryst phase, we have not detected a positive europium anomaly in any of our rare earth patterns for these samples (Staudigel, Hart, and Frey, this volume). This suggests that the plagioclase composition is anorthite-rich and hence does not take up much europium. This is consistent with the relatively calcic plagioclase composition (Table 4) which has worked well in our least-squares calculations (Table 6).

\section{SUMMARY}

Graphical constructions, least-squares calculations, and petrographic observations all indicate that secular crystal accumulation has played an important role in modifying initial liquid compositions. The variation within glasswhole rock pairs can amount to more than the total range observed for the glass compositions.

The cumulate phenocryst assemblages tend to fall into two categories, those in which plagioclase is the only important mineral, and those in which plagioclase is accompanied by olivine and/or pyroxene. The exact nature and extent of the chemical changes depend on the amount and proportions of phenocrysts, but generally involve significant increases in $\mathrm{CaO}$ and $\mathrm{Al}_{2} \mathrm{O}_{3}$ and decreases in $\mathrm{FeO}$ and $\mathrm{TiO}_{2}$ in the 
TABLE 6

Unweighted Least-Squares Approximation to Selected Whole Rock Compositions Calculated as a Linear Combination of the Equivalent Glass Composition and the Average Phenocryst Mineral Compositions in Table 1

\begin{tabular}{|c|c|c|c|c|c|c|c|c|}
\hline & \multicolumn{8}{|c|}{ MgO-Enriched Trends } \\
\hline & \multicolumn{2}{|c|}{$417 \mathrm{D}-42-5$} & \multicolumn{2}{|c|}{$418 \mathrm{~A}-79-4$} & \multicolumn{2}{|c|}{$418 \mathrm{~A}-73-1$} & \multicolumn{2}{|c|}{$418 \mathrm{~A}-76-1$} \\
\hline & $\mathrm{A}$ & B & $\mathrm{A}$ & B & $\mathrm{A}$ & B & $\mathrm{A}$ & B \\
\hline $\mathrm{SiO}_{2}$ & 50.18 & 49.96 & 50.46 & 50.37 & 49.97 & 50.08 & 49.56 & 50.13 \\
\hline $\mathrm{TiO}_{2}$ & 1.39 & 1.57 & 1.18 & 1.24 & 1.20 & 1.29 & 1.21 & 1.31 \\
\hline $\mathrm{Al}_{2} \mathrm{O}_{3}$ & 15.93 & 15.89 & 15.33 & 15.43 & 16.02 & 16.11 & 16.41 & 16.54 \\
\hline $\mathrm{FeO}$ & 9.97 & 9.99 & 9.47 & 9.79 & 9.53 & 9.72 & 9.34 & 9.32 \\
\hline $\mathrm{MgO}$ & 7.10 & 7.14 & 7.53 & 7.57 & 7.76 & 7.84 & 7.51 & 7.70 \\
\hline $\mathrm{CaO}$ & 12.98 & 12.99 & 13.10 & 13.29 & 12.34 & 12.53 & 11.97 & 12.09 \\
\hline $\mathrm{Na}_{2} \mathrm{O}$ & 2.11 & 2.18 & 2.02 & 1.74 & 2.10 & 2.05 & 2.21 & 2.40 \\
\hline \multicolumn{9}{|l|}{ Glass/ } \\
\hline mass & 0.7944 & 0.732 & 0.7346 & 0.799 & 0.7948 & 0.770 & 0.8373 & 0.856 \\
\hline Plag. & 0.1328 & 0.201 & 0.1461 & 0.151 & 0.1395 & 0.180 & 0.1330 & 0.116 \\
\hline Cpx & 0.0659 & 0.022 & 0.1021 & 0.033 & 0.0315 & 0.040 & 0.0314 & 0.027 \\
\hline Olivine & 0.0105 & 0.045 & 0.011 & 0.017 & 0.0361 & 0.010 & -0.0072 & - \\
\hline
\end{tabular}

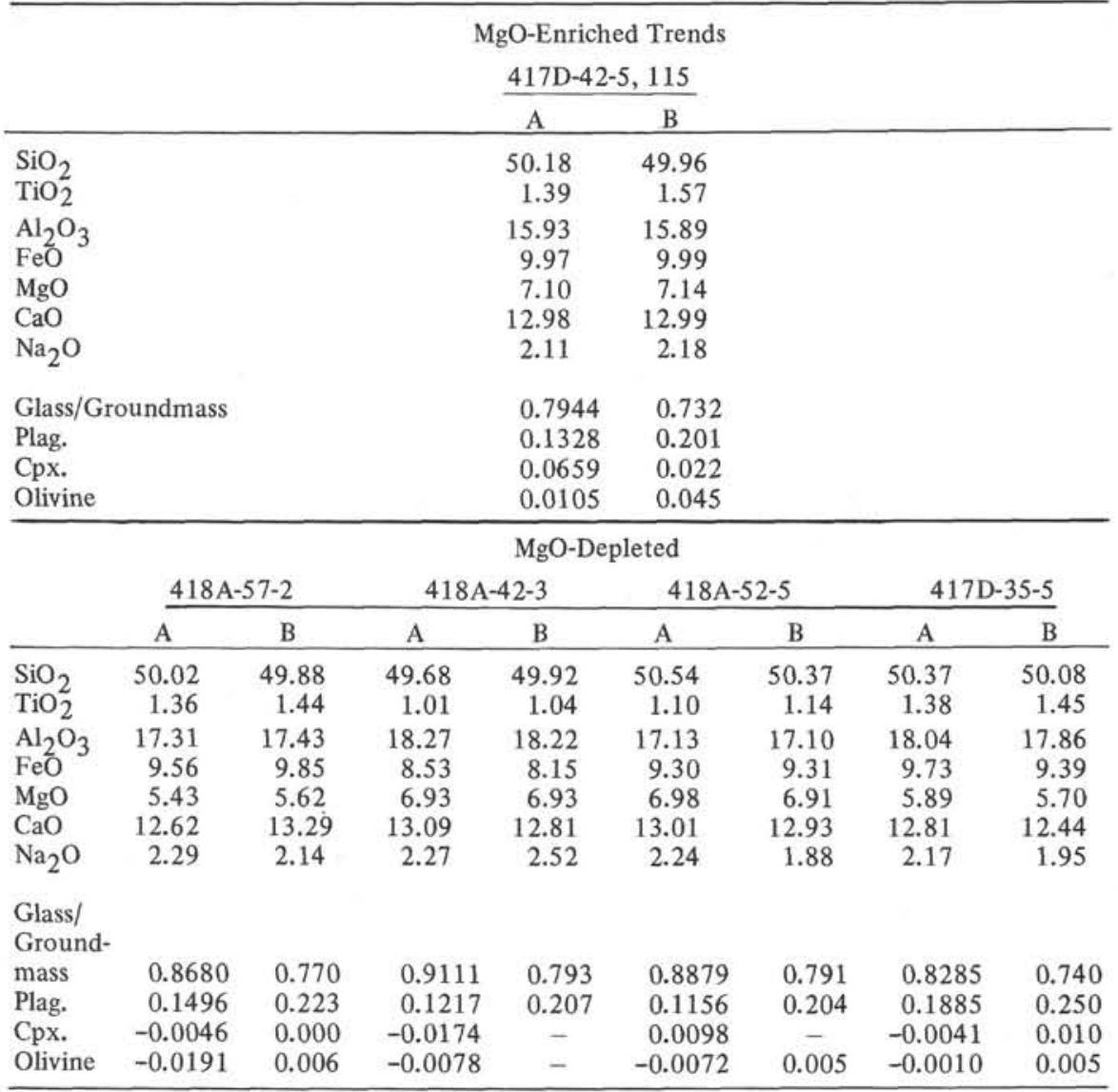

Note: The oxides $\mathrm{MnO}, \mathrm{K}_{2} \mathrm{O}$, and $\mathrm{P}_{2} \mathrm{O}_{5}$ were not included in the calculations due to deficiencies in the data base or to uncertainties introduced by weathering effects. In each pair, composition A is calculated, B is observed. See text for discussion of data normalization. Glass and mineral proportions given as weight fractions of mixture.

whole rock data compared to glasses. As is made especially clear by vectors and glass-whole rock pairs plotted in Figure 6 , these cumulate phenocryst effects produce considerable scatter in the whole rock data and may significantly change the slope or even the sign of major element covariances in the whole rock compared to the glass data. We conclude from whole rock trace element and major element data, and from microprobe glass analyses, that the magmas at Holes 417 and 418A were formed from a very homogeneous source (by high degree of partial melting) and were subsequently modified by two magmatic processes: shallow level crystal fractionation which yielded the variation in liquid (glass) composition; and by phenocryst redistribution by crystal settling or floating in thick flows and/or dynamic 
sorting in lava tubes or dikes which yielded the variation in whole rock compositions. This latter process seems to be particularly important in subaqueous lava systems where laminar flow in thin dikes and in lava tubes is more common than turbulent flow, which is less efficient in redistributing phenocrysts. We have shown by calculations (Table 6) and graphic representation (Figure 6) that rather small amounts (2-3\%) of a mineral of rather extreme composition, such as olivine or titanomagnetite can significantly modify "characteristic" chemical parameters like $\mathrm{FeO}, \mathrm{MgO}$, and $\mathrm{TiO}_{2}$ while plagioclase produces significant variations in $\mathrm{Al}_{2} \mathrm{O}_{3}$ and $\mathrm{CaO}$. These locally produced compositional changes contribute to the scatter of whole rock data and tend to mask or even to reverse subtle variation trends in the basalt liquids, represented by the glass data. We suggest that these liquid (glass) compositions are much more likely to reflect fundamental magmatic processes; at least they should be easier to interpret as they should have little or no compositional "overprint" due to alteration and crystal accumulation.

The nature of phenocryst assemblages may still provide important clues to physical processes operating on magmas. It is not clear, for example, why phenocryst assemblages should tend to fall into two distinct populations, but such relations have been observed before, for example in the FAMOUS area (Bryan and Moore, 1977). Such contrasted populations might arise from mixing of two distinct magmas, or could depend on whether segregation is accomplished primarily by gravity or by a dynamic process such as flow differentiation. It is evident that basalts from Holes 417D and 418A provide many opportunities for more detailed investigation of such processes.

\section{ACKNOWLEDGMENTS}

We thank Brian Schroeder, Don Bankston, and Margaret Sulanowska for help in the laboratory, and G. Byerly and J. Sinton for providing additional glass analyses. The manuscript was critically reviewed by F.A. Frey. H. Staudigel was supported by ONR Grant N-00014-75-C0291 to S.R. Hart, and at an early stage by the Deutsche Forschungsgemeinschaft, a travel grant was provided by the Fulbright Foundation. Bryan and Thompson were supported by NSF Grant OCE-15858. All support is gratefully acknowledged.

\section{REFERENCES}

Abbey, S., 1976. SY-2, SY-3 and MRG-1 report on the collaborative analysis of three Canadian rock samples for use as certified reference materials - Supplement I, Canmet Rept. 76-36, Energy Mines and Resources Canada, Ottawa.

Brown, G.C., Hughes, D.J., and Esson, J., 1973. New xrf data retrieval techniques and their application to USGS standard rocks, Chem. Geol., v. 11, p. 223-229.

Bryan, W.B. and Moore, J.G., 1977. Compositional variation of young basalts in the Mid-Atlantic Ridge rift valley near latitude $36^{\circ} 49^{\prime}$ N, Geol. Soc. Am. Bull., v. 88, p. 556-570.

Bryan, W.B. and Sargent, D., 1979. Basalts from $22^{\circ}-23^{\circ} \mathrm{N}$ Mid-Atlantic Ridge median valley. In Melson, W.G., Rabinowitz, P.D., et al., Initial Reports of the Deep Sea Drilling Project, v. 45: Washington (U.S. Government Printing Office), p.

Bryan, W.B. and Thompson, G., 1977. Basalts from DSDP Leg 37 and the FAMOUS area: compositional and petrogenetic comparisons, Canadian J. Earth Sci., v. 14, p. 875-885.

Bryan, W.B., Thompson, G., Frey, F.A., and Dickey, J.S., 1976. Inferred geologic settings and differentiation in basalts from the Deep Sea Drilling Project, J. Geophys. Res., v. 81, p. $4285-4304$.

Flanagan, F.J., 1978. Values for international geochemical reference samples, Geochim. Cosmochim. Acta. v. 37, p. 1189-1200.

Frey, F.A., Bryan, W.B., and Thompson, G., 1974. Atlantic Ocean floor: geochemistry and petrology of basalts from Legs 2 and 3 of the Deep Sea Drilling Project, J. Geophys. Res., v. 79 , p. 5507-5527.

Hart, S.R. and Brooks, C., 1974. Clinopyroxene matrix partitioning of $\mathrm{K}, \mathrm{Rb}, \mathrm{Cx}, \mathrm{Sr}$ and $\mathrm{Ba}$, Geochim. Cosmochim. Acta, v. 38, p. $1799-1806$.

Melson, W.G., Thompson, G., and van Andel, T.H., 1968. Volcanism and metamorphism in the Mid-Atlantic Ridge, $22^{\circ} \mathrm{N}$ latitude, J. Geophys. Res., v. 73, p. 5925-5941.

Melson, W.G., Vallier, T.L., Wright, J.L., Byerly, G., and Nelen, J., 1976. Chemical diversity of abyssal volcanic glass erupted along Pacific, Atlantic and Indian Ocean floor spreading centers. In Geophysics of Pacific Ocean Basin and its Margins, Geophys. Monogr., v. 19, p. 351-363.

Norrish, K. and Hutton, J.T., 1969. An accurate X-ray spectrographic method for the analysis of a wide range of geologic samples, Geochim. Cosmochim. Acta, v. 33, p. 431-453.

Schilling, J.G., 1975. Azores mantle blob: rare earth evidence, Earth Planet. Sci. Lett., v. 25, p. 103-115.

Thompson, G., 1973. A geochemical study of the low temperature interaction of sea water and ocean igneous rocks, EOS, Trans. Am. Geophys. Union, v. 54, p. 1015-1019.

Thompson, G. and Bankston, D.C., 1969. A technique for trace element analysis of powdered materials using the d.c. arc and photoelectric spectrometry, Spectrochim. Acta, v. 24B, p. $335-350$. 